\title{
Thermodynamic Evaluation of Energy Integration and Cogeneration in Ammonium Nitrate Production Complexes*
}

\author{
Z. Kirova-Yordanova \\ University "Prof. Assen Zlatarov", 1, Prof. Yakimov Str., 8010 Bourgas, Bulgaria \\ e-mail: zkirova@btu.bg, zornitzakirova@yahoo.co.uk
}

\begin{abstract}
The energy integration and cogeneration are commonly used in large nitrogen and phosphorous fertilizer production complexes, due to the presence of highly exothermic reactions, e.g. nitric and/or sulphuric acid plants and heat consuming processes, e.g. urea, ammonium nitrate, wet phosphoric acid, complex fertilizers. In this work the exergy method is used to analyze the dependence of the primary energy consumption and GHG emissions in the ammonium nitrate production on basic parameters of the subsystems (ammonia, nitric acid and ammonium nitrate production units and CHP) and on the allocation of the additional fuel (natural gas) burning and steam generation. The results show that the most effective allocation scheme depends on the relative efficiencies of the subsystems as well as on the boundary conditions and regulations of the GHG emissions.
\end{abstract}

\section{Keywords: Ammonium nitrate; energy integration; cogeneration; exergy; GHG emissions.}

\section{Introduction}

Fertilizer grade ammonium nitrate contains 33.5 - 34\% $\mathrm{N}$ and is the second (after urea) straight nitrogen fertilizer most used worldwide, especially appropriate for the temperate zone climate and soils.

The ammonium nitrate production chain includes three consecutive technological steps: production of ammonia from natural gas, production of nitric acid from ammonia and finally, synthesis of ammonium nitrate from ammonia and nitric acid.

The world ammonia production is an energy intensive process, consuming annually about 4500 PJ fossil fuels, mainly natural gas as the most favorable feedstock and also as fuel and emitting roughly about 250 million tons $\mathrm{CO}_{2}$. A complex steam and power generation subsystem satisfies all the needs from steam and power in the modern ammonia plants and, if necessary, some quantities of MP or LP steam could be exported.

On the contrary, nitric acid production is a highly exothermic process, producing and exporting steam (or electricity) as a useful by-product. However, the $\mathrm{N}_{2} \mathrm{O}$, emitted from the process is equivalent to up to about 2 tons $\mathrm{CO}_{2}$ per ton produced $\mathrm{HNO}_{3}$.

Ammonium nitrate synthesis is also an exothermic process, but the heat of the reaction is released at a low temperature level and practically can't be used for steam generation; furthermore some import steam is consumed in the process and the problem is where this steam could be generated more effectively and with less greenhouse gases (GHG) emissions. In an ammonium nitrate production site three possible steam generation sources exist: ammonia plant, nitric acid plant and/or a CHP.

As both ammonia and nitric acid plants exist in various design configurations, there does not exist a single best solution of the problem. The goal is to find a solution that would minimize both the natural gas consumption and the
GHG emissions from the overall production site. In most cases the problem is more complicated due to the presence of other fertilizer production processes in the same site, e.g. phosphoric acid and phosphorous and/or complex fertilizers production, all of them consuming significant quantities of steam.

In previous work (Kirova-Yordanova, 1999, 2011, 2012; Kirova-Yordanova et al., 1994, 1995) the exergy method (Szargut et al., 1988) was used to estimate the efficiency of the energy integration of the particular processes and units (ammonia plants and nitric acid plants). The conclusion was made that the non-integrated ammonia plants are more efficient than that of energy-integrated ones (KirovaYordanova et al., 1995) because the steam-and-power generation subsystem in ammonia plants is less efficient than in modern CHP plants. This conclusion is confirmed in a later work (Kirova-Yordanova, 2012), when the parametric sensibility of the efficiency in both kind of ammonia plants was studied. The analysis shows that the minimum natural gas consumption (and the minimum $\mathrm{CO}_{2}$ emissions, respectively) would be obtained if the power (and HP steam) generation would be shifted from ammonia plant to CHP plant. On the contrary, concerning nitric acid plants, the conclusion was made (Kirova-Yordanova, 2011; Kirova-Yordanova et al., 1994) that a particular case of the energy integrated plants with Non Selective Catalytic Reduction (NSCR) unit, where some additional fuel is burned, are more efficient than conventional plants, because the parameters of the tail gas energy recovery subsystem are much higher than in CHP plants. Besides that, the NSCR ensures a high degree of all nitrogen oxides $\left(\mathrm{NO}_{\mathrm{x}}\right.$ and $\left.\mathrm{N}_{2} \mathrm{O}\right)$ removal from the tail gas and thus the total GHG emissions are lower.

In this work the exergy method is used to analyze the dependence of the primary energy consumption and GHG emissions in the ammonium nitrate production on basic 
parameters of the subsystems (ammonia, nitric acid and ammonium nitrate production units and CHP) and on the allocation of the additional fuel (natural gas) burning and steam generation.

\section{Nitrogen Fertilizers Production Background: Basic Reactions and Heat Effects}

The structure of the building block model of an ammonium nitrate production site is shown in Figure 1. The site includes production of ammonia and nitric acid as intermediates, synthesis of ammonium nitrate as a final product and (in some cases) a combined steam and power plant (CHP).

Despite that nitrogen fertilizers production is well known as an energy intensive industry branch, from a mere thermodynamic point of view, the basic reactions of the nitrogen fertilizers production processes are exothermic and the overall reactions of the both process routes (ammonium nitrate and urea production routes) are also exothermic. This means that, if all these reactions could be performed in a thermodynamically ideal way, e.g. in an ideal engine or fuel cell, some heat and/or power could be obtained from these reactions, not to be consumed.

\subsection{Ammonia Production: Endothermic and Exothermic Reactions}

The commercial ammonia manufacture is based on the catalytic synthesis of ammonia from hydrogen and nitrogen, known as Haber - Bosch process. The extraction of nitrogen from the atmospheric air is a relatively easy task, whereas, a lot of energy and many steps are necessary to obtain hydrogen from water, which is the main hydrogencontaining source. If a part of the hydrogen is supplied by another hydrogen-containing feedstock, like hydrocarbons, energy requirements are less. Thus the most favourable feedstock for ammonia production is the natural gas $\left(\mathrm{CH}_{4}\right)$ because in this case only a half of the hydrogen is obtained from water.

However, hydrogen production from hydrocarbons and water is a strongly endothermic process, hence a considerable amount of high temperature heat is necessary to be introduced into the process, practically by burning of some quantity of fuel with air.

The combination of both steam reforming and burning processes makes it possible to obtain the hydrogen-nitrogen mixture directly, avoiding the air separation as a preliminary step. Thus the two-step steam and air reforming of hydrocarbons has been the best industrial process for the preparation of hydrogen-nitrogen mixture for over 60 years (Appl, 1999; European Commission. Directorate - General JRC, 2007; European Fertilizers Manufacturers Association, 2000).

Assuming roughly the oxygen and nitrogen content in air as $20 \%$ and $80 \%$ respectively, the following basic reactions of ammonia production from natural gas $\left(\mathrm{CH}_{4}\right)$ could be written:

$$
\begin{aligned}
& 3 / 8 \mathrm{CH}_{4(\mathrm{~g})}+3 / 8 \mathrm{H}_{2} \mathrm{O}_{(\mathrm{g})}=3 / 8 \mathrm{CO}_{(\mathrm{g})}+9 / 8 \mathrm{H}_{2(\mathrm{~g})}-77.3 \mathrm{~kJ} \\
& 3 / 8 \mathrm{CO}_{(\mathrm{g})}+3 / 8 \mathrm{H}_{2} \mathrm{O}_{(\mathrm{g})}=3 / 8 \mathrm{CO}_{2(\mathrm{~g})}+3 / 8 \mathrm{H}_{2(\mathrm{~g})}+15.5 \mathrm{~kJ} \\
& 1 / 8 \mathrm{O}_{2}+4 / 8 \mathrm{~N}_{2}+1 / 16 \mathrm{CH}_{4} \\
& \quad=1 / 16 \mathrm{CO}_{2}+1 / 8 \mathrm{H}_{2} \mathrm{O}+4 / 8 \mathrm{~N}_{2}+50.1 \mathrm{~kJ} \\
& 12 / 8 \mathrm{H}_{2}+4 / 8 \mathrm{~N}_{2}=\mathrm{NH}_{3}+46.2 \mathrm{~kJ}
\end{aligned}
$$

Summarizing reactions (1), (2), (3) and (4), the total ammonia production process could be expressed by the formal reaction:

$$
\begin{aligned}
3.5 / 8 \mathrm{CH}_{4(\mathrm{~g})}+5 / 8 \mathrm{H}_{2} \mathrm{O}_{(\mathrm{g})}+1 / 8 \mathrm{O}_{2}+4 / 8 \mathrm{~N}_{2} \\
=\mathrm{NH}_{3(\mathrm{~g})}+3.5 / 8 \mathrm{CO}_{2(\mathrm{~g})}+34.5
\end{aligned}
$$

Thus the overall heat of reactions in ammonia production is slightly positive. But if water enters into the process as a liquid, the overall reaction is nearly thermally neutral:

$$
\begin{aligned}
3.5 / 8 \mathrm{CH}_{4(\mathrm{~g})}+5 / 8 \mathrm{H}_{2} \mathrm{O}_{(\mathrm{l})}+1 / 8 \mathrm{O}_{2}+4 / 8 \mathrm{~N}_{2} \\
=\mathrm{NH}_{3(\mathrm{~g})}+3.5 / 8 \mathrm{CO}_{2(\mathrm{~g})}+6.98 \mathrm{~kJ}
\end{aligned}
$$

\subsection{Nitric Acid Production: All Reactions Exothermic}

The nitric acid production process is based on three main reactions as follows:

Catalytic oxidation of ammonia in air to nitric oxide:

$$
\mathrm{NH}_{3}+5 / 4 \mathrm{O}_{2}=\mathrm{NO}+6 / 4 \mathrm{H}_{2} \mathrm{O}_{(\mathrm{g})}+226.3 \mathrm{~kJ}
$$

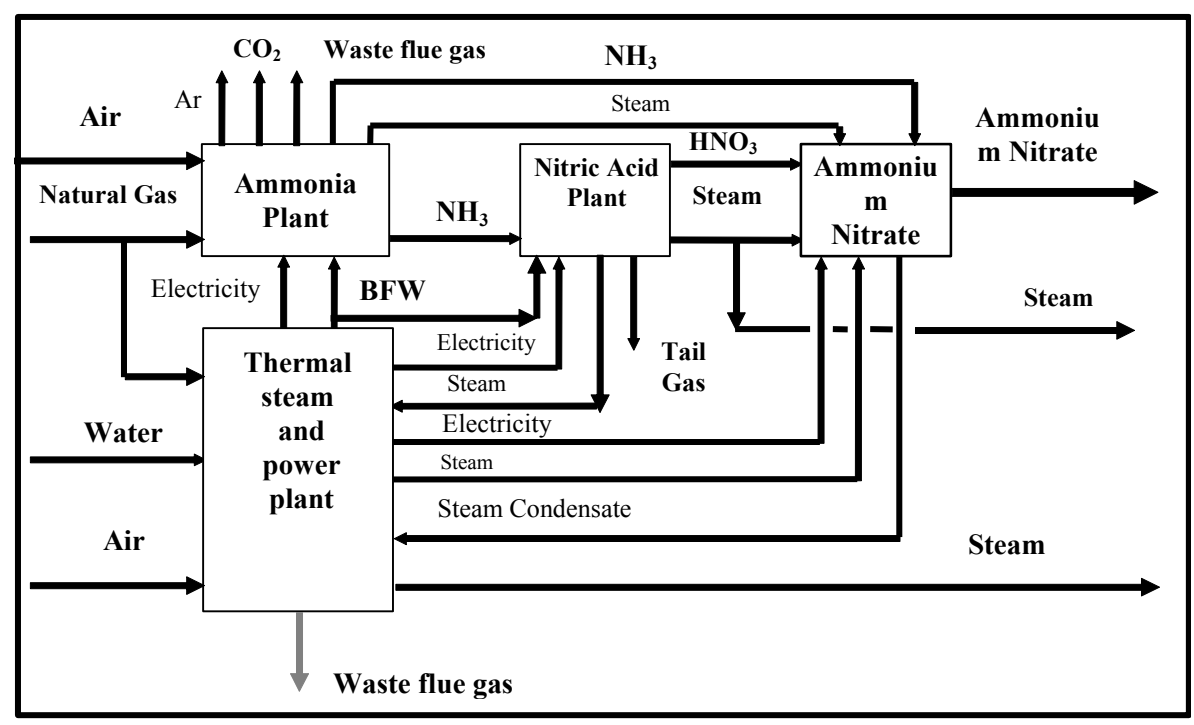

Figure 1. The structure of the building block model of an ammonium nitrate production site. 
Table 1. Heat of reactions and Gibbs free energy in basic chemical processes of the natural gas-based production of ammonium nitrate.

\begin{tabular}{|c|c|c|c|c|}
\hline \multirow[t]{2}{*}{ Production process } & \multicolumn{2}{|c|}{$\begin{array}{c}\text { Heat of reaction } \\
\left(-\Delta \mathrm{H}, 25^{\circ} \mathrm{C}, 101325 \mathrm{~Pa}\right)\end{array}$} & \multicolumn{2}{|c|}{$\begin{array}{c}\text { Gibbs free energy change } \\
\left(-\Delta \mathrm{G}, 2^{\circ} \mathrm{C}, 101325 \mathrm{~Pa}\right)\end{array}$} \\
\hline & $\begin{array}{c}\mathrm{kJ} / \mathrm{mol} \\
\text { product of } \\
\text { reaction }\end{array}$ & $\begin{array}{c}\text { GJ/t } \\
\mathrm{NH}_{4} \mathrm{NO}_{3}\end{array}$ & $\begin{array}{c}\mathrm{kJ} / \mathrm{mol} \\
\text { product of } \\
\text { reaction }\end{array}$ & $\begin{array}{c}\mathrm{GJ} / \mathrm{t} \\
\mathrm{NH}_{4} \mathrm{NO}_{3}\end{array}$ \\
\hline Ammonia from $\mathrm{CH}_{4}$ by reaction (6) & 6.98 & 0.087 & 18.74 & 0.234 \\
\hline Nitric acid from ammonia by reaction (11) & 413.78 & 5.172 & 301.38 & 3.767 \\
\hline Nitric acid from from $\mathrm{CH}_{4}$ by reaction (12) & 420.76 & 5.259 & 320.12 & 4.001 \\
\hline $\begin{array}{l}\text { Ammonium nitrate from ammonia and nitric acid by } \\
\text { reaction (13) }\end{array}$ & 145.10 & 1.814 & 86.30 & 1.079 \\
\hline Ammonium nitrate from $\mathrm{CH}_{4}$ by reaction (14) & 572.84 & 7.160 & 425.15 & 5.314 \\
\hline
\end{tabular}

Table 2. Theoretical and actual minimum natural gas (methane) consumption in ammonium nitrate production.

\begin{tabular}{|c|c|c|c|c|c|c|c|c|}
\hline \multirow[t]{2}{*}{ Production process } & \multicolumn{2}{|c|}{$\begin{array}{c}\text { Theoretical } \\
\text { (stoichiometric) } \\
\text { minimum } \\
\text { by reactions (6), (12) } \\
\text { and (14) }\end{array}$} & \multicolumn{2}{|c|}{$\begin{array}{c}\text { Theoretical } \\
\text { minimum } \\
\text { (methane as } \\
\text { feedstock and fuel } \\
\text { for chemical } \\
\text { processes only) }[6]\end{array}$} & \multicolumn{2}{|c|}{$\begin{array}{l}\text { Actual minimum } \\
\text { (incl. methane for } \\
\text { shaft work } \\
\text { generation in } \\
\text { ammonia } \\
\text { production) }[6]\end{array}$} & \multicolumn{2}{|c|}{$\begin{array}{l}\text { Actual minimum } \\
\text { incl. nitrogen losses } \\
\text { in nitric acid } \\
\text { production }\end{array}$} \\
\hline & $\begin{array}{c}\mathrm{GJ} / \mathrm{t} \\
\text { product }\end{array}$ & $\begin{array}{c}\mathrm{GJ} / \mathrm{t} \\
\mathrm{NH}_{4} \mathrm{NO}_{3}\end{array}$ & $\begin{array}{c}\mathrm{GJ} / \mathrm{t} \\
\text { product }\end{array}$ & $\begin{array}{c}\mathrm{GJ} / \mathrm{t} \\
\mathrm{NH}_{4} \mathrm{NO}_{3}\end{array}$ & $\begin{array}{c}\mathrm{GJ} / \mathrm{t} \\
\text { product }\end{array}$ & $\begin{array}{c}\mathrm{GJ} / \mathrm{t} \\
\mathrm{NH}_{4} \mathrm{NO}_{3}\end{array}$ & $\begin{array}{c}\mathrm{GJ} / \mathrm{t} \\
\text { product }\end{array}$ & $\begin{array}{c}\mathrm{GJ} / \mathrm{t} \\
\mathrm{NH}_{4} \mathrm{NO}_{3}\end{array}$ \\
\hline Ammonia from $\mathrm{CH}_{4}$ & 20.648 & 4.388 & 22.206 & 4.719 & 27.445 & 5.832 & 27.445 & 5.832 \\
\hline Nitric acid & 5.572 & 4.388 & 5.992 & 4.719 & 7.406 & 5.832 & 7.715 & 6.075 \\
\hline Ammonium nitrate & \multicolumn{2}{|c|}{8.776} & \multicolumn{2}{|c|}{9.438} & \multicolumn{2}{|c|}{11.664} & \multicolumn{2}{|c|}{11.907} \\
\hline
\end{tabular}

Homogeneous oxidation of $\mathrm{NO}$ to $\mathrm{NO}_{2}$ :

$\mathrm{NO}+1 / 2 \mathrm{O}_{2}=\mathrm{NO}_{2}+56.8 \mathrm{~kJ}$

Absorption of $\mathrm{NO}_{2}$ in water:

$\mathrm{NO}_{2}+1 / 3 \mathrm{H}_{2} \mathrm{O}_{(\mathrm{l})}=2 / 3 \mathrm{HNO}_{3(1)}+1 / 3 \mathrm{NO}+24.2 \mathrm{~kJ}$

As NO, formed by reaction (9), has also to be oxidized to $\mathrm{NO}_{2}$, the total reaction of nitric acid formation from $\mathrm{NO}$, oxygen and water is the following:

$\mathrm{NO}+3 / 4 \mathrm{O}_{2}+1 / 2 \mathrm{H}_{2} \mathrm{O}_{(\mathrm{l})}=\mathrm{HNO}_{3(\mathrm{l})}+121.5 \mathrm{~kJ}$

The overall heat of nitric acid formation from ammonia and oxygen by the total reaction:

$\mathrm{NH}_{3(\mathrm{~g})}+2 \mathrm{O}_{2(\mathrm{~g})}=\mathrm{HNO}_{3(\mathrm{l})}+\mathrm{H}_{2} \mathrm{O}_{(\mathrm{l})}+413.8 \mathrm{~kJ}$

is $369.7 \mathrm{~kJ} / \mathrm{mol} \mathrm{HNO}_{3}$ or $413.8 \mathrm{~kJ} / \mathrm{mol} \mathrm{HNO}_{3}$ when the water, formed by the total nitric acid production process is in the gas or in the liquid phase, respectively.

However, only about one half of the overall heat of reaction, namely the heat of ammonia oxidation, is released at high temperature. The reaction (7) is performed at relatively low temperature, thus the exergy of the released heat is small. The heat released by the reaction (9), which is provided at a near to ambient temperature, is practically unusable (Table 2).

Summarizing reactions (6) and (11), the total nitric acid production process from natural gas $\left(\mathrm{CH}_{4}\right)$ could be expressed by the overall reaction:

$$
\begin{aligned}
& 3.5 / 8 \mathrm{CH}_{4}+17 / 8 \mathrm{O}_{2}+4 / 8 \mathrm{~N}_{2} \\
& \quad=\mathrm{HNO}_{3(1)}+3 / 8 \mathrm{H}_{2} \mathrm{O}_{(\mathrm{l})}+3.5 / 8 \mathrm{CO}_{2}+420.8 \mathrm{~kJ}
\end{aligned}
$$

\subsection{Ammonium Nitrate Synthesis and Overall Reaction}

Ammonium nitrate synthesis from ammonia and nitric acid:

$\mathrm{NH}_{3(\mathrm{~g})}+\mathrm{HNO}_{3(\mathrm{l})}=\mathrm{NH}_{4} \mathrm{NO}_{3(\mathrm{~s})}+145.1 \mathrm{~kJ}$ is also an exothermic reaction.

Summarizing reactions (6), (11) and (13), the overall reaction of ammonium nitrate production process from air, liquid water and natural gas $\left(\mathrm{CH}_{4}\right)$ as feedstock, could be presented as:

$7 / 8 \mathrm{CH}_{4(\mathrm{~g})}+2 / 8 \mathrm{H}_{2} \mathrm{O}_{(\mathrm{l})}+18 / 8 \mathrm{O}_{2(\mathrm{~g})}+8 / 8 \mathrm{~N}_{2(\mathrm{~g})}$

$=\mathrm{NH}_{4} \mathrm{NO}_{3(\mathrm{~s})}+7 / 8 \mathrm{CO}_{2(\mathrm{~g})}+572.8 \mathrm{~kJ}$

The overall reaction (14) is strongly exothermic and the heat of this reaction is significant: $572.8 \mathrm{~kJ} / \mathrm{mol} \mathrm{NH}{ }_{4} \mathrm{NO}_{3}(7.836$ $\mathrm{GJ} / \mathrm{t} \mathrm{NH}_{4} \mathrm{NO}_{3}$ ). The results of the above calculations are presented in Table 1 .

2.4 Theoretical and Actual Feedstock and Fuel Consumption in Ammonium Nitrate Production

The theoretical (on the stoichiometric basis) methane consumption for ammonia, nitric acid and ammonium nitrate production, according the equations (1) - (14), is presented in Table 2. The actual consumption of natural gas (methane) is much higher than the theoretical value.

The theoretical minimum of methane, including its consumption as feedstock and fuel, necessary for chemical processes only, is calculated in (Kirova-Yordanova, 2012) as $22.206 \mathrm{GJ} / \mathrm{t} \mathrm{NH}_{3}$. The actual minimum estimated as 27.445 $\mathrm{GJ} / \mathrm{t} \mathrm{NH}_{3}$, includes also the methane burned for the shaft work generation at the highest (up to now) adiabatic efficiencies of the steam turbines and isothermal efficiencies of the main compressors in ammonia plants (KirovaYordanova, 2012).

These theoretical and actual values of the methane consumed in ammonia production are used to calculate (on a stoichiometric basis) the methane consumed for the nitric acid and ammonium nitrate production (Table 2). In the last column a minimum of $4 \%$ unavoidable fixed nitrogen losses (in ammonia oxidation and NOx absorption processes) are included. Thus the actual minimum methane consumption in 
modern BAT ammonium nitrate production plants is about $35 \%$ higher than the theoretical (stoichiometric) minimum (Table 2).

\section{Energy Integration in an Ammonium Nitrate Production Site}

The energy integration in an ammonium nitrate production site should be analyzed in two aspects. The first one is the energy integration in each particular production process, especially in ammonia and nitric acid plants. The second is the energy integration in the overall site, including the CHP plant. In this case the problem is whether it would be more effective to burn some fuel to provide a chemical plant with power and/or steam in the energy-integrated chemical plant itself or in a CHP plant at the same industrial site.

A modern energy-integrated chemical plant is a combination of a chemical and a power plant, producing, besides the chemical products itself, also shaft work and steam. The HP or MP steam is generated using the heat of the exothermic reactions and some additional fuel is burned if needed. The shaft work is generated by steam and/or gas turbines and is used to drive compressors and other machinery. The MP and LP steam, extracted from the turbine, is used then as a reagent and/or a heating agent and partly is exported to other plants in the site. In the case of multiple steam consuming units in the site, a CHP plant is included in the production complex.

\subsection{Energy Integration and Export Steam Generation in Ammonia Plants}

The question is if the export steam generation in ammonia plant is more effective than in a CHP situated in the same industrial site. As it was shown in (KirovaYordanova, 2012), due to the utilization of a part of the available MT\&LT heat released from the chemical processes, the fuel consumption for the shaft work generation in ammonia plants is lower than in power plants working at the same steam parameters.

However, in the latest designs, a strong tendency exists toward lower fuel consumption in ammonia plants and, consequently, the corresponding lower $\mathrm{CO}_{2}$ emissions. Whereas about 5-8 tons HP steam per ton ammonia are generated in ammonia plants designed in the 70s, now the steam generated in the latest design low-energy plants, is about 3 tons per ton ammonia produced (Appl, 1999). As it was shown in (Kirova-Yordanova, 2012), the actual minimum consumption of natural gas (methane) in modern ammonia plants corresponds to the generation of about 2.22.4 tons HP steam per ton ammonia, which is sufficient to generate the shaft work, necessary to drive the main compressors in the plant (Table 3 ). In this case no steam is exported to the site.

The detailed analysis of the available sources and use of the MT\&LT heat in such a low-energy ammonia plant (Table 3), shows that the MT\&LT heat is used mainly for the BFW preheating, but some part is used also for the water evaporation (HP steam generation), despite that the design of the HP boilers in ammonia synthesis unit is more difficult. Hence, if some steam has to be exported from the plant, an appropriate solution could be to use all MT\&LT heat for BFW preheating only. In this case, the HT heat would be insufficient for water evaporation and steam superheating and some additional quantity of natural gas (methane) should be burned. Thus some more HP steam would be generated, the load of the HP case of the steam turbine would rise, and that of the LP case would decrease and the extracted surplus MP steam could be exported. In this scenario, the quantity of the exported steam depends on the efficiencies of the turbines and of the compressors. An example of this case is presented in Table 3 and the dependence of the exported steam on the isothermal efficiency of the compressors is shown in Figure 2. It is clear that this approach makes the steam export rather limited and possible only if the compressors and turbines are highly efficient. The advantage is that the specific consumption of the additional methane, burned in order to generate exported steam, is about $10 \%$ lower than if this steam was generated in the CHP plant (all the parameters of the steam in both units being the same).

It is clear that the steam export from an ammonia plant could be more intensive, but in this case natural gas (methane) would be burned not only for the HP steam superheating and generation (i.e., for HT heat supply), but also for BFW preheating. Thus, the specific consumption of methane, burned to generate the steam exported from ammonia plant, would increase and approximate the corresponding value in the CHP plant.

\subsection{Nitric Acid Production Process: Efficiency of the Exothermic Reaction's Heat Utilization}

All chemical reactions (7-12) in nitric acid production process are exothermic. However, only about one half of the overall heat of reaction, namely the heat of the ammonia oxidation, is released at high temperature $800-900^{\circ} \mathrm{C}$ (Table 4). The most of this HT heat is used to generate MP (or HP) steam, the balance is used to heat the waste gas.

As the equilibrium of the reactions (8) - (10) is more favorable at higher pressures, in modern plants they are performed at 0.8-1.2 $\mathrm{MPa}$. Thus one or two compressors are used to compress the air (or both the air and nitrous gas) to this pressure. However, after the absorption process is finalized, the waste ("tail") gas, containing mainly nitrogen, about $3 \%$ oxygen and small quantities of $\mathrm{NO}_{\mathrm{x}}$ and $\mathrm{N}_{2} \mathrm{O}$, leaves the absorption column at ambient temperature but at a relatively high pressure. In order to use the physical energy of this flow, the waste gas is heated and then expanded in a gas turbine (expander) recovering some part of the shaft work, consumed in the compressors. The shaft work balance is achieved expanding a part of the generated steam in a steam turbine. Thus a high level of integration of chemical and energy-conversion processes is achieved.

The energy integration in chemical processes with exothermic main reactions, as is nitric acid production, could be analyzed in two aspects. The first one is the integration of the chemical and energy conversion processes in nitric acid plants, where the only source of energy is the ammonia feedstock. The goal of the investigations in this field is to optimize the reactions heat utilization and to maximize the energy export (as steam or sometimes as electricity) from the plants. Both pinch and exergy methods are used competitively and remarkable results are achieved in last decades in analysis and optimization of various kinds of nitric acid plants and it seems that the practical limits are reached in this direction (Gaggioli et al., 1991; Linnhof \& Alanis, 1991).

The steam export depends primarily on the tail gas temperature at the gas turbine inlet. In most modern designs this temperature is about $500^{\circ} \mathrm{C}$, but in principle it could be increased up to $700^{\circ} \mathrm{C}$. The higher this temperature is, the more shaft work could be generated in the gas turbine and 
the less part of the work, necessary to drive both compressors could be generated by the steam turbine and consequently more steam could be exported. Thus the steam export in conventional nitric acid plants depends also on the efficiencies of the compressors and turbines.

It is clear from Figure 3 that at gas turbine adiabatic efficiency $\eta_{\mathrm{ad}}=0.7$ and compressors isothermal efficiencies $\eta_{\text {isoth }}=0.56$, the maximum steam export $\left(4 \mathrm{MPa}, 450{ }^{\circ} \mathrm{C}\right)$ would be about $460 \mathrm{~kg} / \mathrm{t} \mathrm{HNO}_{3}$.

The second aspect concerns a special kind of nitric acid plants, where the non-selective catalytic reduction (NSCR) of
NOx and $\mathrm{N}_{2} \mathrm{O}$ by natural gas (methane) or/and hydrogen is used for the tail gas treatment. The process is referred to as NSCR, because the reducing agents interact first with the free oxygen, present in the tail gas, then with $\mathrm{NO}_{2}, \mathrm{NO}$ and $\mathrm{N}_{2} \mathrm{O}$. As the oxygen content in the tail gas is about $3 \%$, the methane reacted in the NSCR unit (on a stoichiometric basis) should be about $50 \mathrm{Nm}^{3} / \mathrm{t} \mathrm{HNO}_{3}$. The heat of the reactions is enough to increase the tail gas temperature up to $500-760^{\circ} \mathrm{C}$ at the NSCR outlet and respectively, at the gas turbine inlet.

Table 3. Energy consumption in modern ammonia production plants.

\begin{tabular}{|c|c|c|c|c|}
\hline \multirow[b]{2}{*}{ Process } & \multicolumn{2}{|c|}{ No steam export } & \multicolumn{2}{|c|}{ Steam export } \\
\hline & $\begin{array}{l}\text { Shaft work } \\
\text { GJ/t NH}\end{array}$ & $\begin{array}{c}\text { Steam } \\
\mathrm{kg} / \mathrm{t} \mathrm{NH}\end{array}$ & $\begin{array}{l}\text { Shaft work } \\
\text { GJ/t NH}\end{array}$ & $\begin{array}{c}\text { Steam } \\
\mathrm{kg} / \mathrm{t} \mathrm{NH}\end{array}$ \\
\hline \multicolumn{5}{|l|}{$\begin{array}{l}\text { Total minimum actual theoretical shaft work } \\
\text { generated in steam turbines } \eta_{\mathrm{ad}}=0.7\end{array}$} \\
\hline - $\quad \mathrm{HP}$ steam $\left(10 \mathrm{MPa}, 500^{\circ} \mathrm{C}\right)$ to $\mathrm{MP}$ steam $4 \mathrm{MPa}$ & 0.422 & 2244 & 0.503 & 2678 \\
\hline - $\quad$ MP steam (4 MPa) to condensation & 0.918 & 1183 & 0.837 & 1078 \\
\hline - $\quad$ MP steam (4 MPa) to the reforming process & - & 1061 & - & 1061 \\
\hline - $\quad$ MP steam (4 MPa) export & - & - & - & 538 \\
\hline Total shaft work generated & 1.340 & & 1.340 & \\
\hline \multicolumn{5}{|c|}{ Heat consumption for HP steam generation in ammonia plant } \\
\hline \multicolumn{5}{|l|}{ Heat consumption for HP steam generation: } \\
\hline - $\quad$ Steam superheating & 1.458 & 2244 & 1.739 & 2678 \\
\hline - Water evaporation & 2.953 & 2244 & 3.524 & 2678 \\
\hline - $\quad$ BF water preheating & 2.857 & 2244 & 3.410 & 2678 \\
\hline Total heat for HP steam generation & 7.268 & 2244 & 8.673 & 2678 \\
\hline \multicolumn{5}{|c|}{ Actual medium and low temperature (MT\&LT) heat available from the process } \\
\hline $\begin{array}{l}\text { MT\&LT heat available for BF water preheating and } \\
\text { water evaporation }\end{array}$ & 3.410 & 2244 & 3.410 & 2678 \\
\hline \multicolumn{5}{|c|}{ High temperature (HT) heat supply by methane burning } \\
\hline \multicolumn{5}{|l|}{ HT heat consumption for HP steam generation: } \\
\hline - Steam superheating & 1.458 & 2244 & 1.739 & 2678 \\
\hline - Water evaporation & 2.400 & 2244 & 3.524 & 2678 \\
\hline Total HT heat consumed for HP steam generation & 3.858 & 2244 & 5.263 & 2678 \\
\hline Heat losses ( $10 \%$ from methane burning heat) & 0.429 & - & 0.585 & - \\
\hline \multicolumn{5}{|l|}{$\begin{array}{l}\text { Total actual HT heat supply by methane burning for } \\
\text { work and steam generation }\end{array}$} \\
\hline - $\quad \mathrm{GJ} / \mathrm{t} \mathrm{NH}_{3}$ & 4.287 & & 5.848 & \\
\hline - $\mathrm{Nm}^{3} / \mathrm{t} \mathrm{NH}_{3}$ & 119.7 & & 163.3 & \\
\hline \multicolumn{5}{|l|}{$\begin{array}{l}\text { Actual minimum methane consumption for chemical } \\
\text { process in ammonia production }\end{array}$} \\
\hline - $\mathbf{G J} / \mathbf{t} \mathrm{NH}_{3}$ & 22.711 & & 22.711 & \\
\hline - $\mathrm{Nm}^{3} / \mathrm{t} \mathrm{NH}_{3}$ & 634.1 & & 634.1 & \\
\hline \multicolumn{5}{|l|}{ Actual consumption for work generation in power plants } \\
\hline - $\quad \mathrm{GJ} / \mathrm{t} \mathrm{NH}_{3}$ & 0.447 & & 0.447 & \\
\hline - $\mathrm{Nm}^{3} / \mathrm{t} \mathrm{NH}_{3}$ & 12.5 & & 12.5 & \\
\hline \multicolumn{5}{|l|}{ Total actual consumption in ammonia plants: } \\
\hline - $\quad \mathrm{GJ} / \mathrm{t} \mathrm{NH}_{3}$ & 27.445 & & 29.006 & \\
\hline - $\mathrm{Nm}^{3} / \mathrm{t} \mathrm{NH}_{3}$ & 766.3 & & 809.9 & \\
\hline \multicolumn{5}{|l|}{ Specific methane consumption for exported steam: } \\
\hline - GJ/t exported steam & - & & 2.90 & \\
\hline - $\mathrm{Nm}^{3} / \mathrm{t}$ exported steam & - & & 81.0 & \\
\hline
\end{tabular}




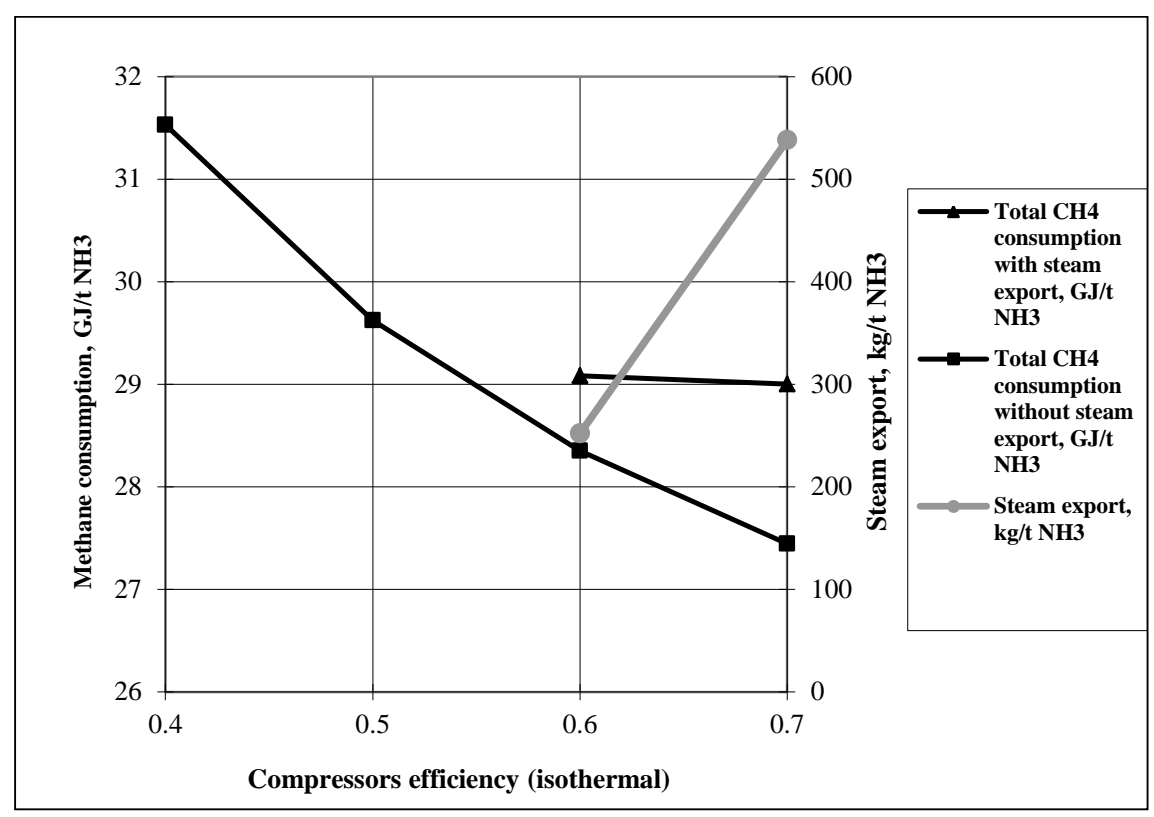

Figure 2. Dependence of the total methane consumption on the isothermal efficiencies of the main compressors in ammonia production plants without and with steam export. Steam turbines adiabatic efficiency $\eta_{a d}=0.7$. Exported steam parameters: 4.0 $\mathrm{MPa}, 450^{\circ} \mathrm{C}$.

Table 4. Theoretical heat balance of the nitric acid production process: available heat.

\begin{tabular}{|c|c|c|c|c|}
\hline \multirow[t]{2}{*}{ Production process } & \multicolumn{2}{|c|}{$\begin{array}{c}\text { Heat of reaction } \\
\left(-\Delta \mathrm{H}, 25^{\circ} \mathrm{C}, 101325 \mathrm{~Pa}\right)\end{array}$} & \multirow{2}{*}{$\begin{array}{l}\text { Average reaction } \\
\text { temperature, }{ }^{0} \mathrm{C}\end{array}$} & \multirow{2}{*}{$\begin{array}{c}\text { Exergy of heat } \\
\text { GJ/t } \mathrm{HNO}_{3}\end{array}$} \\
\hline & $\mathrm{kJ} / \mathrm{mol} \mathrm{HNO}_{3}$ & $\mathrm{GJ} / \mathrm{t} \mathrm{HNO}_{3}$ & & \\
\hline \multicolumn{5}{|c|}{ High temperature heat available } \\
\hline Catalytic oxidation of ammonia to NO & 226.3 & 3.591 & 850 & 2.638 \\
\hline \multicolumn{5}{|c|}{ Low temperature heat available } \\
\hline Oxidation of $\mathrm{NO}$ to $\mathrm{NO}_{2}$ & 56.8 & 0.901 & $30-200$ & 0.140 \\
\hline Absorption of $\mathrm{NO}_{2}$ to $\mathrm{HNO}_{3}$ & 64.7 & 1.027 & 30 & 0.017 \\
\hline Total LT heat supply by reactions & 121.5 & 1.928 & & 0.157 \\
\hline Water vapour condensation & 66.0 & 1.048 & $85-30$ & 0.103 \\
\hline Total LT heat supply & 187.5 & 2.976 & & 0.260 \\
\hline Total heat supply & 413.8 & 6.568 & & 2.898 \\
\hline
\end{tabular}

Depending on the efficiency and the inlet temperature of the gas turbine, it generates all (or near all) shaft work to drive both compressors and consecutively all (or near all) MP steam, produced in the plant, could be exported or used to generate electricity, if no needs of steam export exist in the site. In this case the quantity of the exported steam is $1500-1700 \mathrm{~kg} / \mathrm{t} \mathrm{HNO}_{3}$, which is much more than the export from the conventional plants (Figure 3 ).

The question arises of whether the methane burning in such a kind of nitric acid plants would be advantageous, compared to burning in a CHP plant.

The data from Figure 3 show that the specific consumption of methane, burned in the NSCR unit, is about $30-35 \mathrm{Nm}^{3} / \mathrm{t}$ exported steam, which is much lower than if this methane would be burned in a CHP plant. Thus the methane usage as a reducing agent in the NSCR units causes the most favourable effect on the steam generation in comparison with the steam generation in ammonia plants and in CHP plants.

In some plants some additional methane (over the stoichiometric quantity) is burned in order to increase the temperature of the waste gas incoming into the gas turbine, especially if the efficiencies of the compressors are relatively low. However, in this case, the methane cannot be burned in or after the NSCR unit at the tail gas pressure, as no more oxygen is presented in this gas at the turbine inlet. Consequently, the additional methane could only be used for an additional heating of the tail gas in order to fit the overall shaft work balance of the plant. Thus if additional methane would be burned, the efficiency of the export steam generation would decrease, but it would be still higher than in ammonia plant or in CHP plant.

\subsection{Comparison of the Export Steam Generation Efficiency in Ammonia, Nitric acid and CHP Plants}

Some results of the analysis of the export steam generation in ammonium nitrate production sites are shown in Table 5. Two basic examples were analyzed:

- export steam generation in ammonia plant and in a conventional nitric acid plant;

- export steam generation in ammonia plant and in a nitric acid plant with NSCR unit. 


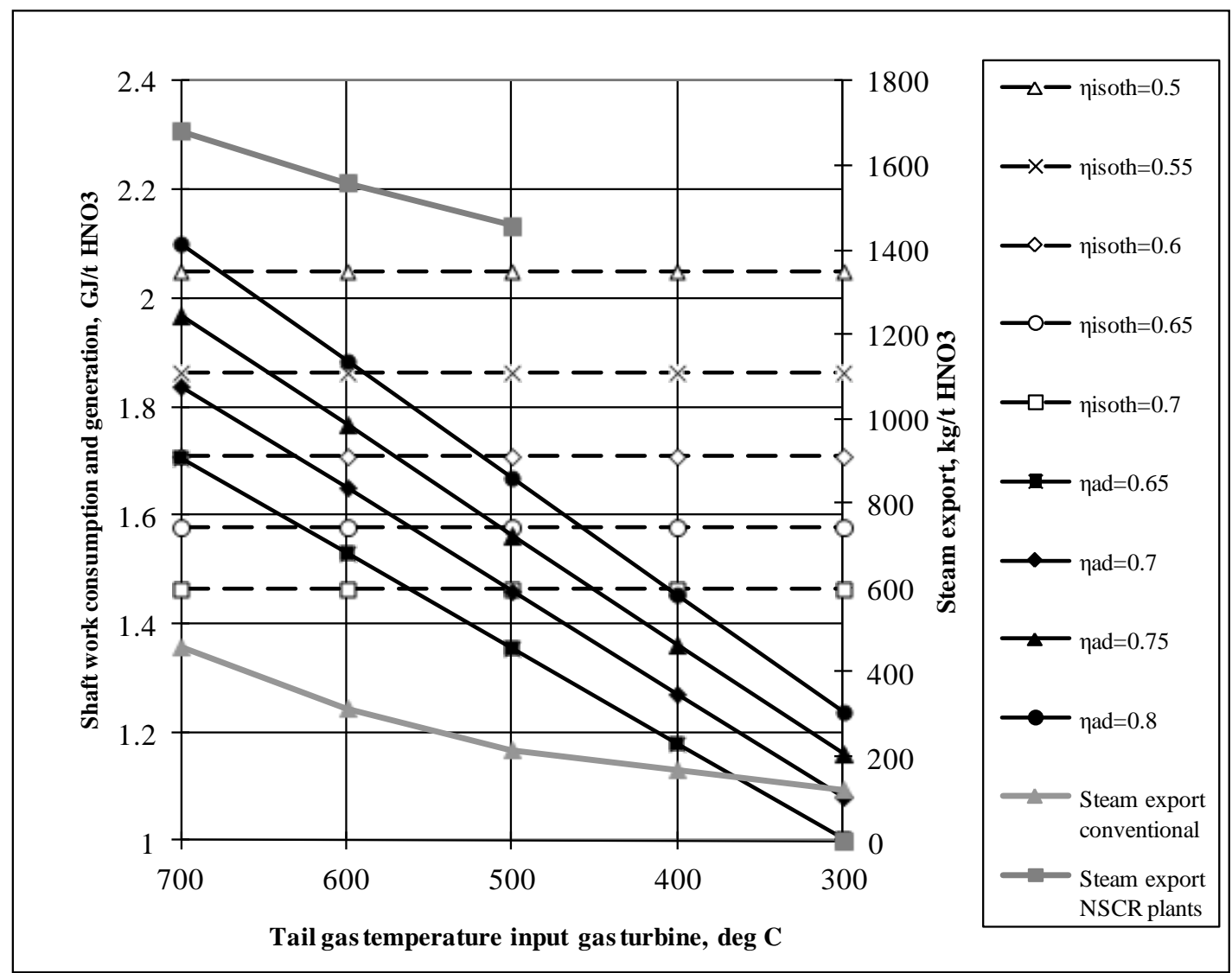

Figure 3. Shaft work consumption / generation and steam export from nitric acid production plants. Solid lines: Shaft work generation by the tail gas expansion turbine at various adiabatic efficiencies. Dashed lines: Shaft work consumption by the air- and nitrous gas- compressors at various isothermal efficiencies. Light grey line: Steam export $\left(4.0 \mathrm{MPa}, 450^{\circ} \mathrm{C}\right)$ from conventional plants; Gas turbine adiabatic efficiency $\eta_{\text {ad }}=0.7$; compressors isothermal efficiencies $\eta_{\text {isoth }}=0.56$. Dark grey line: Steam export $\left(4.0 \mathrm{MPa}, 450^{\circ} \mathrm{C}\right)$ from plants with $\mathrm{NSCR}\left(50 \mathrm{Nm} 3 \mathrm{CH}_{4} / \mathrm{HNO}_{3}\right.$ burned in the NSCR reactor).

In the first (and the most widespread) case the maximum quantity of the export steam generated at the most favourable conditions in modern ammonia and nitric acid plants is about $600 \mathrm{~kg} / \mathrm{t} \mathrm{NH}_{4} \mathrm{NO}_{3}$, which is more than enough to meet the needs of a modern ammonium nitrate plant. About $60 \%$ of this quantity is generated in nitric acid plant, the balance - in ammonia plant. Hence, if the needs in the site are lower, the steam could be generated in the nitric acid plant only and no methane could be consumed for the steam generation. Moreover, if the ammonium nitrate plant does not import steam, the energy surplus in nitric acid plant could be used for electricity generation. On the contrary, if the needs in the site are higher, then more export steam could be generated in ammonia plant, as this was discussed in 3.1. In all cases, the steam generation in a CHP plant is not necessary and is less efficient than in a nitric acid or an ammonia plant.

In the second case the maximum quantity of the export steam generated is much more and approaches about 1500 $\mathrm{kg}$ steam per ton ammonium nitrate. The specific methane consumption is about 3 times lower than in a CHP plant. This case is especially appropriate if other steam consuming production units (e.g. urea, wet process phosphoric acid, etc.) are situated in the same site.

In all cases, in ammonium nitrate production sites it is more efficient to generate steam in the nitric acid and ammonia plants than in a CHP plant, even though some additional methane should be burned.

An example of the exergy balance of a modern lowenergy ammonium nitrate complex is shown in Figure 4 The exergy consumption values in ammonia plant correspond to the basic case ammonia plant with steam export presented in Table 3 . In this case additional methane is burned only for the evaporation and superheating of the high pressure steam, not for BFW preheating. The steam generation in conventional nitric acid plant correspond to the highest input gas turbine temperature $\left(700^{\circ}\right)$ of the tail gas (Figure 3). The total exergy losses are $8.9 \mathrm{GJ} / \mathrm{t}$ ammonium nitrate and the exergy degree of perfection of the overall ammonium nitrate complex is $33.3 \%$.

\section{Conclusions}

The most effective method for steam generation in an ammonium nitrate production site is to use the reaction heat of ammonia oxidation in a maximally effective way. Up to $500 \mathrm{~kg}$ MP steam per ton produced nitric acid could be generated without fuel consumption in the conventional nitric acid plant if the temperature at the gas turbine inlet is $700^{\circ} \mathrm{C}$ and the efficiencies of the turbine and both compressors are high.

If the steam needs in the site are much higher than it is possible to generate in a conventional nitric acid plant, the best option is to have a nitric acid plant with an NSCR unit. In this case up to $1700 \mathrm{~kg}$ MP steam per ton produced nitric acid could be generated, consuming about $50 \mathrm{Nm}^{3}$ methane / $\mathrm{t} \mathrm{HNO}_{3}$. The specific consumption of methane in this case is about $1 / 3$ of the specific methane consumption in a CHP plant. The lower methane consumption for the steam generation in the nitric acid and ammonia production plants has as a positive effect also lower $\mathrm{CO}_{2}$ emissions than in CHP plants, by up to $60 \mathrm{~kg} \mathrm{CO} / \mathrm{t}$ ammonium nitrate if the complex includes a conventional nitris acid plant. 
If the nitric acid plant is equipped with a NSCR unit, the reduction of $\mathrm{CO}_{2}$ emissions could be about $140 \mathrm{~kg} \mathrm{CO} / \mathrm{t}$ ammonium nitrate, compared with a CHP plant.

An additional positive effect is created in the NSCR units, where the quantity of the $\mathrm{N}_{2} \mathrm{O}$ emissions in the tail gas is reduced about 10 times, resulting in a $\mathrm{CO}_{2}-$ equivalent reduction of about $2000 \mathrm{~kg} / \mathrm{t} \mathrm{HNO}_{3}$.

\section{Nomenclature}

BAT Best Available Technique

BFW Boiler Feed Water

CHP Combined Heat and Power

HP High Pressure, $\mathrm{MPa}$

HT High Temperature, ${ }^{0} \mathrm{C}$
LHV Low Heating Value, kJ

LP Low Pressure, MPa

LT Low temperature, ${ }^{0} \mathrm{C}$

MP Middle Pressure, MPa

MT Middle Temperature, ${ }^{0} \mathrm{C}$

NSCR Non-Selective Catalytic Reduction of NOx and $\mathrm{N}_{2} \mathrm{O}$

$\eta_{a d} \quad$ adiabatic (isenthropic) efficiency of a turbine, $\eta_{a d}=w / w_{a d}$

$\eta_{\text {isoth }}$ isothermal efficiency of a compressor, $\eta_{\text {isoth }}=w_{\text {isoth }} / w$

Table 5. Methane consumption and $\mathrm{CO}_{2}$ emissions from the export steam generation sources in ammonium nitrate production sites

\begin{tabular}{|c|c|c|c|c|c|c|c|}
\hline \multirow[t]{2}{*}{$\begin{array}{l}\text { Export MP steam } \\
\text { generation sources }\end{array}$} & \multicolumn{2}{|c|}{ Export steam, $\mathrm{kg} / \mathrm{t}$} & \multicolumn{2}{|c|}{$\begin{array}{l}\text { Methane } \\
\text { consumption }\end{array}$} & \multicolumn{3}{|c|}{$\begin{array}{l}\text { Specific methane consumption } \\
\text { and } \mathrm{CO}_{2} \text { emissions }\end{array}$} \\
\hline & $\mathrm{kg} / \mathrm{t}$ product & $\begin{array}{c}\mathrm{kg} / \mathrm{t} \\
\mathrm{NH}_{4} \mathrm{NO}_{3}\end{array}$ & $\begin{array}{l}\mathrm{Nm}^{3} / \mathrm{t} \\
\text { product }\end{array}$ & $\begin{array}{c}\mathrm{Nm}^{3} / \mathrm{t} \\
\mathrm{NH}_{4} \mathrm{NO}_{3}\end{array}$ & $\begin{array}{l}\mathrm{Nm}^{3} / \mathrm{t} \\
\text { steam }\end{array}$ & $\begin{array}{c}\mathrm{GJ} / \mathrm{t} \\
\mathrm{NH}_{4} \mathrm{NO}_{3} \\
\end{array}$ & $\begin{array}{l}\mathrm{kg} \mathrm{CO} / \mathrm{t} \\
\mathrm{NH}_{4} \mathrm{NO}_{3}\end{array}$ \\
\hline $\begin{array}{l}\text { Ammonia plant } \\
\text { Nitric acid plant: }\end{array}$ & 538 & 233 & 43.6 & 19 & 81 & 0.67 & 37 \\
\hline - conventional & 460 & 362 & - & - & - & - & - \\
\hline $\begin{array}{l}\text { - with NSCR unit } \\
\text { Total from: }\end{array}$ & $1500-1700$ & $1180-1340$ & 50 & $35-47$ & $30-35$ & $1.25-1.68$ & $69-92$ \\
\hline $\begin{array}{l}\text {-ammonia \& conventional } \\
\text { nitric acid plant } \\
\text {-ammonia \& nitric acid plant }\end{array}$ & - & 595 & - & 19 & 32 & 0.67 & 37 \\
\hline with NSCR & - & $1413-1573$ & - & $54-66$ & $38-42$ & $1.93-2.36$ & $105-130$ \\
\hline $\begin{array}{l}\text { CHP plant, the equal quantity } \\
\text { of steam exported }\end{array}$ & - & $\begin{array}{c}595 \\
1413-1573\end{array}$ & - & $\begin{array}{c}54 \\
127-142\end{array}$ & $\begin{array}{l}90 \\
90\end{array}$ & $\begin{array}{c}1.93 \\
4.55-5.07\end{array}$ & $\begin{array}{c}105 \\
250-279\end{array}$ \\
\hline $\begin{array}{l}\text { Reduction of methane } \\
\text { consumption and } \mathrm{CO}_{2} \\
\text { emissions in: }\end{array}$ & & & & & & & \\
\hline $\begin{array}{l}\text {-ammonia \& conventional } \\
\text { nitric acid plant }\end{array}$ & - & - & - & 35 & 58 & 1.26 & 68 \\
\hline $\begin{array}{l}\text {-ammonia \& nitric acid plant } \\
\text { with NSCR }\end{array}$ & - & - & - & $73-76$ & $52-48$ & $2.62-2.71$ & $145-148$ \\
\hline
\end{tabular}

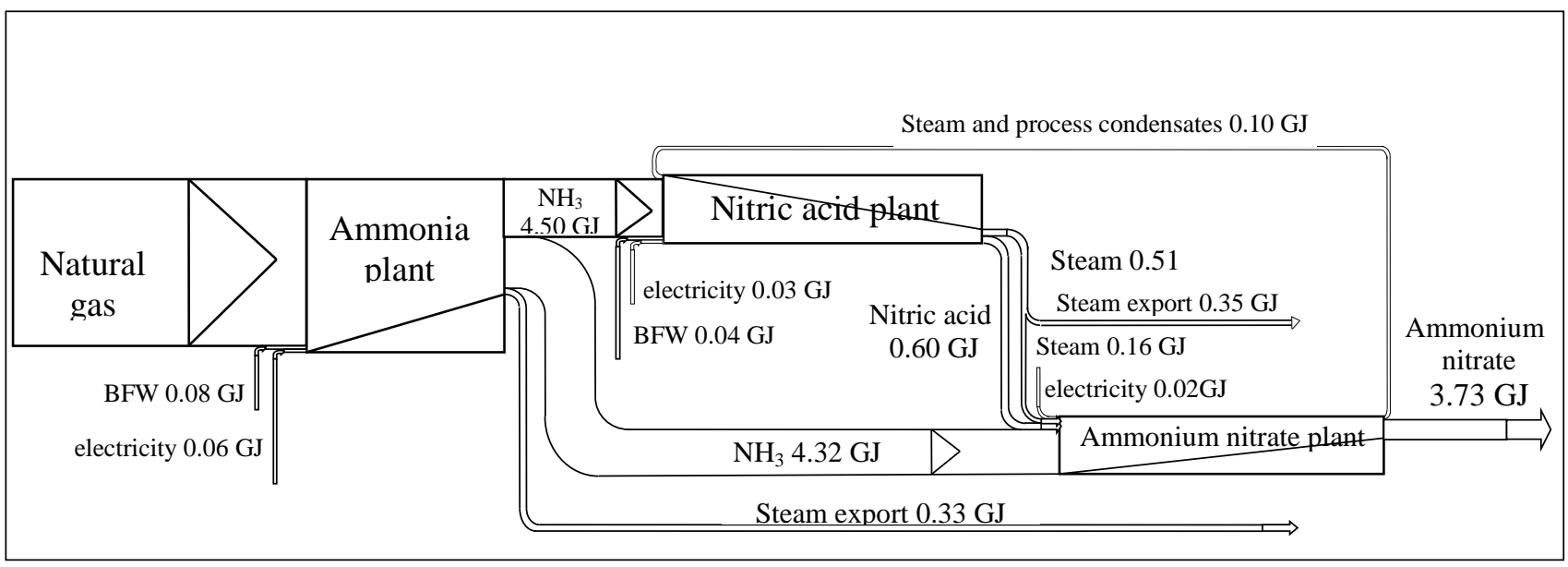

Figure 4. Exergy flows (Grassmann) diagram of a modern ammonium nitrate production complex with conventional nitric acid plant. Exergy flows dimension: GJ per metric ton ammonium nitrate.The gas flows released to the environment (flue gas and $\mathrm{CO}_{2}$ from ammonia plant, tail gas from nitric acid plant) are not shown. 


\section{References:}

Appl, M. (1999). Ammonia: Principles and Industrial Practice. New York, NY:Wiley-VCH Verlag.

European Fertilizers Manufacturers Association. (2000). Best Available Techniques for Pollution Prevention and Control in the European Fertilizer Industry: Booklet N 1: Production of Ammonia; Booklet N2: Production of Nitric Acid. Booklet $N$ 6: Production of Ammonium Nitrate and Calcium Ammonium Nitrate. Brussels. EFMA. Retrieved October 20. 2013 from: http://www.fertilizerseurope.com/index.php?id=6\&tx_tt news[pointer] $=6 \& \mathrm{cHash}=03 \mathrm{f} 23 \mathrm{~b} 4186 \mathrm{c} 65 \mathrm{~b} 87 \mathrm{~d} 137 \mathrm{acc} 15$ da4c6ab

Gaggioli, R. A., Sama, D. A., Qian, S. \& El-Sayed, M. (1991). Integration of a New Process into an Existing Site: A case Study in the Application of Exergy Analysis, J. of Engineering for Gas Turbines and Power; 113, 170-183.

European Commission. Directorate-General JRC. (2007). Integrated Pollution Prevention and Control. Reference Document on Best Available Techniques in the Large Volume Inorganic Chemicals, Ammonia, Acids and Fertilizers Industrie. EC/ JRC/ IPTS. Seville, Spain. Retrieved October 20, 2013, from: http://eippcb.jrc.ec.europa.eu/reference/BREF/lvic_aaf. pdf.

Kirova-Yordanova, Z. (1999). Energy Integration in Chemical Plants: The Pros and Cons. A Second LawBased Evaluation of Industrial Experience. PI'99. Proceedings of the Inernational. Conference on Process Integration. Copenhagen, Denmark, Vol. 2, pp. 78-80.

Kirova-Yordanova, Z. (2011). Application of the exergy method to environmental impact estimation: The nitric acid production as a case study, Energy 36, 3733-3744.

Kirova-Yordanova, Z. (2012). Energy Integration and Cogeneration in Nitrogen Fertilizers Industry: Thermodynamic Estimation of the Efficiency, Potentials, Limitations and Environmental Impact. Part
1: Energy Integration in Ammonia Production Plants, ECOS 2012: Proceedings of the $25^{\text {th }}$ International Conference on Efficiency, Cost, Optimization, Simulation and Environmental Impact on Energy Systems, Perugia, Italy, Vol. II, 138-152. Retrieved October 20, 2013, from: http://www.fupress.com/Archivio/pdf\%5C5493.pdf.

Kirova - Yordanova, Z., Barakov, Y., Koleva, D. (1994). Exergy Analysis of Nitric Acid Plants: a Case Study. ENERGY FOR THE 21st CENTURY: Conversion, Utilisation and Environmental Quality: Proceedings of the Florence World Energy Research Symposium, 931939.

Kirova-Yordanova, Z., Hrusulev, G., Atanasova, L. (1995). Exergy Analysis of Ammonia Plants: A Comparison of Energy-Integrated and Non-Integrated Plants. ECOS'95: Proceedings of the ASME International Conference Efficiency, Costs, Optimization, Simulation and Environmental Impact of Energy Systems. Istanbul, Turkey, Vol. 1, $237-242$.

Kongshaug, G. (1998). Energy Consumption and Greenhouse Gas Emissions in Fertilizer Production. IFA Technical Conference 1998: Proceedings of the IFA Technical Conference, Marrakech, Morocco. Retrieved October 20, 2013, from: http://www.fertilizer.org/ifa/Home-

Page/LIBRARY/Publication-database.html/EnergyConsumption-and-Greenhouse-Gas-Emissions-inFertilizer-Production.html.

Linnhoff, B., Alanis, F.J. (1991). Integration of a New Process into an Existing Site: A case Study in the Application of Pinch Technology, J.of Engineering for Gas Turbines and Power, 113, 159-169.

Szargut, J., Morris, D. R., Steward, F. R. (1988). Exergy Analysis of Thermal, Chemical and Metallurgical Processes, New York, NY: Hemisphere Publishing Co. 